\title{
Aplikasi Pupuk Hayati Konsorsium Strain Bacillus sp dengan Berbeda Konsentrasi dan Cara Pemberian Terhadap Pertumbuhan Bibit Pala (Myristica fragrans Houtt)
}

\author{
A.Marthin Kalay ${ }^{1 *}$, Henry Kesaulya ${ }^{1}$, Abraham Talahaturuson ${ }^{1}$, \\ Herman Rehatta ${ }^{1}$, Reginawanti Hindersah ${ }^{2}$, \\ ${ }^{1}$ Fakultas Pertanian, Universitas Pattimura. Jl. Ir. M. Putuhena, kampus poka Ambon, 97233. \\ ${ }^{2}$ Fakultas Pertanian, Universitas Padjadjaran, Jl. Raya Jatinangor Bandung. \\ *Korespondensi : marthin.kalay@faperta.unpatti.ac.id
}

\begin{abstract}
ABSTRAK
Pertumbuhan bibit pala membutuhkan kecukupan nutrisi melalui mekanisme kerja bakteri yang berasosiasi dengan perakaran maupun di daun. Penelitian ini bertujuan untuk mengetahui pengaruh pemberian pupuk hayati konsorsium stain Bacillus sp $(\mathrm{PBH})$ pada bibit pala. Perlakuan yang digunakan adalah tanpa pemberian pupuk hayati konsorsium strain Bacillus sp (0\% PHB) sebagai control dan pemberian PBH dengan 0,15\% dan 0,30\% dan dengan cara semprot pada daun dan kocor pada tanah sekitar pangkal batang. Perlakuan dirancang menggunakan rancangan acak lengkap dengan sembilan tanaman sampel per perlakuan setiap kali pengamatan dan didekstruksi. Hasil penelitian ditemukan bahwa pemberian PHB dengan konsentrasi $0,15 \%$ dan $0,30 \%$, dan diaplikasikan pada bibit pala dengan cara disemprot pada tanaman di bagian daun dan dikocor pada tanah sekitar pangkal batang tanaman berpengaruh terhadap tinggi tanaman, bobot kering tajuk, bobot kering akar dan bobot kering tanaman, tetapi tidak berpengaruh terhadap jumlah akar, panjang akar, diameter batang, dan rasio bobot kering tajuk dan akar pada bibit tanaman pala umur empat bulan setelah tanam di polibag. Pemberian PBH dengan konsentrasi 0,30\% lebih baik meskipun diaplikasikan dengan cara disemprot atau di siram, dan ini merupakan solusi untuk meningkatkan pertumbuhan bibit pala secara natur dan berkelanjutan.
\end{abstract}

Kata kunci: Bacillus sp., Myristica fragrans, pala, pupuk hayati, tanaman rempah.

\section{Application of Biofertilizer Consortium of Strain Bacillus sp with Different Concentrations and Aplication Methods on Growth of Nutmeg Seeds (Myristica fragrans Houtt)}

\begin{abstract}
The growth of nutmeg seeds requires adequate nutrition by mechanism of bacteria activity associated with roots and leaves. The aim of study was to determine the effect of application of bacillus strain consortium biofertilizer on nutmeg seedlings. The experiment was arranged by using completely randomized design with $0 \%$ of $\mathrm{PBH}$ as control, and $0.15 \%$ and $0,30 \%$ of $\mathrm{PBH}$ concentration by spraying to leaves and by pouring in the soil around the stem, respectivelly. The results showed that the application of $0.15 \%$ and $0.30 \%$ of PBH concentration has significant effect in plant height, shoot dry weight, dry weight root and plant dry weight, but not at the number of root, root length, stem diameter, and the ratio of shoot and root dry weight of nutmeg seedlings after four month planting in the polybag. The concentration of $\mathrm{PBH} 0.30 \%$ has a greater influence on the nutmeg seed growth, and can be a solution to increasee seed growth.
\end{abstract}

Keywords: Bacillus sp., Myristica fragrans, nutmeg, biological fertilizer, spice plants. 


\section{PENDAHULUAN}

Tanaman pala (Myristica fragrans Houtt) merupakan salah satu komoditas unggulan Maluku selain cengkeh. Di Maluku, Tanaman ini dibudidayakan secara turuntemurun menggunakan sistem perkebunan campuran dalam kearifan lokal yang disebut budidaya dusung atau agroforestri (agroforestry sistem dusung) ${ }^{[1]}$.

Budidaya tanaman pala diawali dengan pembibitan dari biji. Pertumbuhan bibit dari biji sampai bibit siap pindah ke lapangan membutuhkan waktu kurang lebih satu tahun bergantung dari media semai. Menurut petani yang tergabung dalam kelompok tani di Desa Lilibooy Kabupaten Mauluku Tengah yang dibina oleh Dinas Pertanian Provinsi Maluku untuk menakar bibit pala bahwa bibit yang baik untuk bisa dipindahkan kelapangan berumur satu tahun, jumlah daun mencapai 1520 helai, tinggi tanaman 50-60 cm, dan memiliki cabang ke dua, dengan mengandalkan media tanam (tanah dan Bahan organik) sebagai sumber nutrisi. Hal ini mengakibatkan pertumbuhan bibit dapat mencapat 1,5 tahun belum mencapai ukuran ideal untuk dipindahkan kelapangan.

Beberapa tahun terakhir terlihat ada kecenderungan tanaman pala kurang mendapat perhatian dari petani pemilik dusung. Hal ini terlihat dari luas areal yang ditanam, jumlah produksi, jumlah tanaman muda, jumlah tanaman menghasilkan dan jumlah tanaman yang rusak/tanaman tidak menghasilkan. Tabel 1 memperlihatkan kondisi tanaman pala di Maluku.

Tabel 1. Luas Areal, Produksi, tanaman muda, tanaman menghasilkan, dan Tanaman rusak/tanaman tidak menghasilkan pada Pala selama 5 Tahun Terakhir di Maluku

\begin{tabular}{cccccc}
\hline Tahun & $\begin{array}{c}\text { Luas Area } \\
\text { (ha) }\end{array}$ & $\begin{array}{c}\text { Produksi } \\
\text { (ton) }\end{array}$ & $\begin{array}{c}\text { Tanaman } \\
\text { muda }\end{array}$ & $\begin{array}{c}\text { Tanaman } \\
\text { menghasilkan }\end{array}$ & $\begin{array}{c}\text { Tanaman } \\
\text { rusak/tanaman tidak } \\
\text { menghasilkan }\end{array}$ \\
\hline 2014 & $28.436,0$ & $4.743,0$ & $13.152,0$ & $12.681,0$ & $2.605,0$ \\
2015 & $30.357,0$ & $4.406,0$ & $14.147,0$ & $13.786,0$ & $2.423,0$ \\
2016 & $31.547,4$ & $5.020,2$ & $12.644,5$ & $16.828,6$ & $2.074,3$ \\
2017 & $31.624,1$ & $5.512,1$ & $12.223,0$ & $17.653,0$ & $1.748,0$ \\
2018 & $32.456,0$ & $5.325,0$ & $12.669,0$ & $18.228,0$ & $1.560,0$ \\
\hline
\end{tabular}

Sumber: BPS ${ }^{[2]}$

Penurunan tanaman muda mengindikasikan bahwa petani atau pengusaha tanaman pala tidak berupaya untuk melakukan penanaman tanaman baru, namun data ini tidak sejalan dengan adanya peningkatan luas areal tanaman yang meningkat setiap tahun sebesar 3,23\%. Hal ini dapat dijelaskan bahwa sistem budidaya agroforestri atau dengan sistem dusung dapat menyulitkan pengumpulan data yang akurat.

Untuk meningkatkan keberadaan tanaman muda di lahan untuk nantinya menunjang peningkatan tanaman menghasilkan dan produksi maka, diupayakan menanam tanaman baru. Untuk mempercepat pengadaan tanaman baru dapat mengupayakan memacu pertumbuhan tanaman dipembibitan dengan kondisi tanaman yang sehat. Penggunaan pupuk hayati merupakan suatu solusi mempercepat pertumbuhan tanaman.

Pupuk hayati adalah produk biologi yang mengandung mikroorganisme, yang dapat menjaga lingkungan tanah tetap sehat melalui fiksasi nitrogen, pelarutan fosfat dan kalium atau mineralisasi, pelepasan zat pengatur tumbuh tanaman, serta produksi senyawa antibiotik dan biodegradasi bahan organik ${ }^{[3]}$. Umumnya mikro-organisme yang terdapat di dalam pupuk hayati adalah mikroorganisme yang dapat berperan sebagai penambat 
nitrigen, pelarut fosfat, perombak bahan organik, serta penghasil siderofor dan hormon tumbuh seperti IAA, giberelin, sitokinin, dan etilen ${ }^{[4]}$. Mikroorganisme dari genus Bacillus adalah kelompok bakteri pelarut fosfat ${ }^{[5,6]}$, dapat berperan melarutkan fosfat mengikat nitrogen bebas, memproduksi fitohormon, enzim, dan mensintesis siderofor ${ }^{[7,8]}$.

Penelitian ini bertujuan untuk mengetahui pengaruh pemberian pupuk hayati konsorsium stain Bacillus sp pada bibit pala yang diaplikasikan dengan konsentrasi dan cara yang berbeda.

\section{BAHAN DAN METODE}

Penelitan dilaksanakan di Rumah Kaca Fakultas Pertanian Universitas Pattimura Ambon, berlangsung bulan Juli - November 2018. Penelitian menggunakan bibit pala varietas Banda yang berumur 10 minggu yang disemai dari biji di polybag, tanah regosol, pupuk kotoran ayam, pupuk hayati konsorsium strain Bacillus sp (PHB) dengan populasi lebih dari $10^{7} \mathrm{CFU} / \mathrm{mL}$. Karakteristik dari strain Bacillus sp disajikan pada Tabel $2^{[7]}$.

Tabel 2. Karakteristik strain Bacillus sp

\begin{tabular}{lll}
\hline No. & Strain Bakteri & Karakter Fungsional PGPR \\
\hline 1. & Bacillus subtilis & Memproduksi : enzim ACC-deaminase, Fitohormon (IAA, GA), \\
& Strain SWI16b & $\begin{array}{l}\text { HCN; mengikat nitrogen bebas; melarutkan fosfat; mensintesis } \\
\text { siderofor, katekol. }\end{array}$ \\
2. & $\begin{array}{l}\text { Bacillus mojavensis } \\
\text { Strain JCEN3 }\end{array}$ & $\begin{array}{l}\text { Memproduksi : enzim ACC-deaminase, Fitohormon (IAA, GA), } \\
\text { HCN; mengikat nitrogen bebas; melarutkan fosfat; mensintesis } \\
\text { siderofor, katekol. }\end{array}$ \\
3. & Bacillus subtilis & $\begin{array}{l}\text { Memproduksi : enzim ACC-deaminase, Fitohormon (IAA, GA), } \\
\text { HCN; mengikat nitrogen bebas; melarutkan fosfat; mensintesis } \\
\text { Sidrain HPC21 }\end{array}$
\end{tabular}

\section{Rancangan Perlakuan}

Penelitian ini dilaksanakan menggunakan pupuk hayati konsorsium strain Bacillus sp (PHB) dengan berbagai konsentrasi yang diberikan dengan cara semprot pada daun dan kocor pada tanah sekitar pangkal batang. Perlakuan sebagai berikut :
A : Tanpa pupuk hayati (kontrol)
B : PHB 0,15\%; semprot pada daun
C : PHB 0,15\% ; kocor pada tanah sekitar pangkal batang
D : PHB 0,30\%; semprot pada daun
E : PHB 0,30 \% ; kocor pada tanah sekitar pangkal batang

Penelitian dirancang menggunakan rancangan acak lengkap (RAL) dengan sembilan tanaman didekstrusi untuk diamati, yakni pada saat tanam, 2 bulan setelah tanam (BST) dan 4 BST. Setiap perlakuan memiliki 27 tanaman, total tanaman yang digunakan adalah 81 tanaman.

\section{Pelaksanaan Penelitian}

Tanah regosol dan kotoran ayam dicampur merata dengan perbandingan 3:1 $(\mathrm{v} / \mathrm{v})$, kemudian sebanyak $5 \mathrm{~kg}$ media dimasukan ke dalam polybag berukuran $20 \mathrm{~cm}$ x $30 \mathrm{~cm}$, diinkubasi selama satu minggu, selanjutnya ditanam dengan bibit pala berumur 10 minggu.

Pupuk hayati konsorsium strain Bacillus sp diencerkan $0,15 \%$ dan $0,30 \%$ dengan air tanah sebelum inokulasi. Untuk setiap konsentrasi dan cara aplikasi, diberikan sebanyak $20 \mathrm{~mL}$, diinokulasikan sejak tanaman berumur satu minggu setelah pindah tanam sampai bibit berumur empat bulan, 
diberikan dua minggu sekali, dengan cara dikocor pada tanah sekitar pangkal batang, dan menyemprot pada tanaman di bagian daun (sesuai perlakuan).

Pemeliharaan tanaman meliputi penyiraman pada pagi dan sore hari bergantung cuaca, dan pemupukan dengan NPK $1 \mathrm{~g}$ per tanaman yang diberikan pada tanaman berumur 1 BST dan 3 BST.

\section{Respons pertumbuhan tanaman}

a. Tinggi tajuk (TT), diukur dari pangkal batang hingga titik tumbuh.

b. Jumlah daun (JD), dihitung berdasarkan daun yang telah membuka sempurna.

c. Bobor kering tajuk (BKT), bobot kering akar (BKA), jumlah akar (JA) dan panjang ajar (PA), dan diameter batang (BD). Panjang akar dihitung panjang akar dari akar yang tumbuh pada akar utama kemudian dijumlahkan, sedangkan jumlah akar dihitung banyaknya akar yang tumbuh pada akar utama.

d. Bobot kering tanaman (BKTa), yakni bobot kering tanaman termasuk tajuk dan akar.

e. Rasio bobot kering tajuk dan bobot kering akar (T/A).

Semua variabel respons tanaman diamati pada saat tanam dan pada tanaman berumur 2 BST dan 4 BST. Hasil pengamatan dilakukan analisis ragam (Anova) dan uji lanjut menggunakan Uji Beda Nyata Terkecil (BNT) 0,05 . Analisis statistik penggunakan software Minitap 18.

\section{HASIL DAN PEMBAHASAN}

Hasil analisis ragam terhadap semua variabel respons yang diamati pada saat tanam dan pada tanaman berumur 2 BST dan 4 BST, disajikan pada Tabel 2. Perlakuan dinyatakan berpengaruhi jika nilai P lebih kecil dari 0,05.

Tabel 2. Hasil Analisis Ragam Variabel Respons Bibit Pala saat tanam, pada umur 2 BST, dan 4 BST setelah aplikasi dengan PHB berbeda konsentrasi dan cara pemberian.

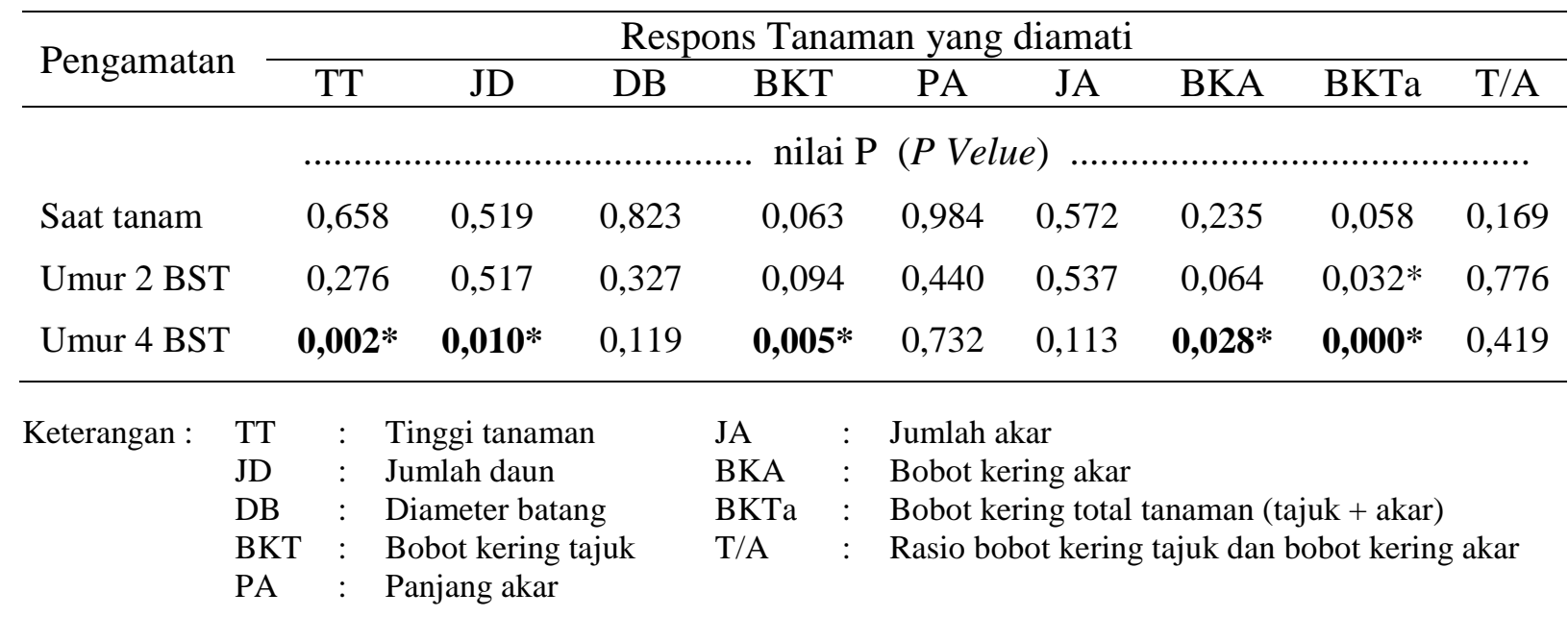

Data pada Tabel 2 memperlihatkan bahwa pemberian PHB dengan berbagai konsentrasi dan cara pemberian berpengaruh signifikan terhadap tinggi tajuk $(\mathrm{P}=0,002)$, jumlah daun $(\mathrm{P}=0,010)$, bobot kering tajuk $(\mathrm{P}=0,005)$, bobot kering akar $(\mathrm{P}=0,028)$, dan bobot kering tanaman $(\mathrm{P}=0,000)$ sedangkan terhadap diameter batang $(\mathrm{P}=0,119)$, panjang akar $(\mathrm{P}=732)$, jumlah akar $(\mathrm{P}=0,113)$, dan rasio tajuk dan akar $(\mathrm{P}=0,419)$ tidak berpengaruh pada bibit pala umur 4 BST. Semua variabel respons tanaman yang diamati saat tanam dan pada umur 2 BST tidak berpengaruh signifikan, kecuali bobot kering 
tanaman $(\mathrm{P}=0,032)$ yang diamati pada umur 2 BST. Hal ini dapat dijelaskan bahwa pemberian PHKSB baru bisa terlihat efektif berpengaruh setelah tanaman berumur 4 BST, disebabkan karena strain Bacillus sp di dalam PHB belum sepenuhnya aktif karena masih dalam keadaan dorman atau penyesuaian tempat hidup sehingga belum dapat membantu menyuburkan tanah melalui mekanisme pelarutan fosfat, dan produksi enzim dan fitohormon.

Hasil penelitian lainnya menjelaskan bahwa bila larutan pupuk hayati disemprotkan pada tanaman atau permukaan tanah, maka mikrobia yang ada belum tentu dapat hidup dan berkembang karena kondisi lingkungan yang mungkin tidak sesuai, antara lain temperatur udara yang terlalu tinggi, kelembaban yang kurang, dan tanpa naungan, menyebabkan mikrobia tersebut tidak berkembang dan mati ${ }^{[9]}$. Selanjutnya dikemukakan juga bahwa para produsen pupuk hayati juga mengandalkan produk ikutan dari pupuk hayati tersebut antara lain enzim dan fitohormon yang diharapkan dapat berpengaruh pada pertumbuhan tanaman, namun keberadaannya dalam jumlah sedikit dan tidak stabil sehingga efeknya pada tanaman juga tidak konsisten.

Selama penelitian berlangsung di rumah kaca, suhu udara sewaktu-waktu dapat mencapai $40-45^{\circ} \mathrm{C}$, sedangkan suhu optimum bagi pertumbuhan bakteri Bacillus adalah 30$40^{0} \mathrm{C}^{[10]}$. Dengan adanya suhu di dalam rumah kaca yang mencapai $45^{\circ} \mathrm{C}$ maka dapat menghambat pertumbuhan dan aktivitas Bacillus. Aktivitas Bacillus untuk memproduksi enzim dan fitohormon membutuhkan suhu $37^{0} \mathrm{C}{ }^{[11]}$, selanjutnya dikemukakan juga bahwa pada suhu yang lebih rendah atau lebih tinggi dari suhu optimum, aktivitas enzim menurun.

Hasil analisis pengaruh dari masingmasing perlakuan terhadap semua variabel respons pada bibit pala berumur 4 BST disajikan pada Tabel 3 dan Gambar 1.

Tabel 3. Hasil analisis uji beda pengaruh perlakuan terhadap bibit pala pada umur 4 BST.

\begin{tabular}{clllll}
\hline \multirow{2}{*}{ Perlakuan } & \multicolumn{5}{c}{ Variabel respons } \\
\cline { 2 - 6 } & \multicolumn{1}{c}{ TT } & \multicolumn{1}{c}{ JD } & \multicolumn{1}{c}{ BKT } & \multicolumn{1}{c}{ BKA } & \multicolumn{1}{c}{ BKTa } \\
\hline & $\ldots . .(\mathrm{cm}) \ldots . .$. & & $\ldots .(\mathrm{g}) \ldots .$. & $\ldots .(\mathrm{g}) \ldots .$. & $\ldots . .(\mathrm{g}) \ldots .$. \\
$\mathrm{A}$ & $15,83(0,76) \mathrm{c}$ & $12,50(1,32) \mathrm{ab}$ & $2,83(0,32) \mathrm{c}$ & $0,87(0,08) \mathrm{b}$ & $3,70(0,31) \mathrm{c}$ \\
$\mathrm{B}$ & $17,20(1,31) \mathrm{bc}$ & $15,67(3,06) \mathrm{a}$ & $3,40(0,46) \mathrm{bc}$ & $1,24(0,12) \mathrm{ab}$ & $4,64(0,48) \mathrm{b}$ \\
$\mathrm{C}$ & $17,00(0,25) \mathrm{c}$ & $9,33(0,58) \mathrm{b}$ & $3,57(0,06) \mathrm{b}$ & $1,63(0,31) \mathrm{a}$ & $5,20(0,36) \mathrm{ab}$ \\
$\mathrm{D}$ & $19,60(0,36) \mathrm{a}$ & $14,33(2,52 \mathrm{a}$ & $4,20(0,17) \mathrm{a}$ & $1,61(0,37) \mathrm{a}$ & $5,81(0,27) \mathrm{a}$ \\
$\mathrm{E}$ & $18,50(0,87) \mathrm{ab}$ & $16,00(1,00) \mathrm{a}$ & $3,90(0,44) \mathrm{ab}$ & $1,30(0,30) \mathrm{ab}$ & $5,20(0,20) \mathrm{ab}$ \\
\hline
\end{tabular}

Keterangan : angka yang diikuti dengan huruf yang tidak sama pada masing-masing perlakuan pada kolom yang sama menunjukkan perbedaan signifikan berdasarkan uji BNT 0,05 (Uji lanjut dari Tabel 2).

Data hasil analisis uji beda pada Tabel 3 menunjukkan bahwa peningkatan konsentrasi pemberian PHB memberikan pengaruh lebih baik terhadap tinggi tanaman, tetapi tidak berpengaruh terhadap jumlad daun, bobot kering tajuk, bobot kering akar dan bobot kering tanaman dimana konsentrasi terbaik adalah $0,30 \%$, sedangkan cara aplikasi tidak memberikan pengaruh yang lebih baik terhadap semua variabel respons yang diamati pada bibit pala umur 4 BST. Hal ini dapat dijelaskan bahwa yang memberikan pengaruh terhadap pertumbuhan bibit pala adalah jika PHB diberikan dengan konsentrasi 0,30\% dan diaplikasikan dengan cara disemprot pada tanaman di bagian daun atau dikocor pada tanah disekitar tanaman. Hal ini dapat disebabkan karena pemberian PHB dengan konsentrasi tinggi erat hubungannya dengan kepadatan populasi Bacillus sp, memungkinkan hasil produksi zat pengatur tumbuh seperti auksin, sitokinin, giberalin, 
etile akan semakin banyak, dan berperan penting dalam memacu pertumbuhan tanaman.
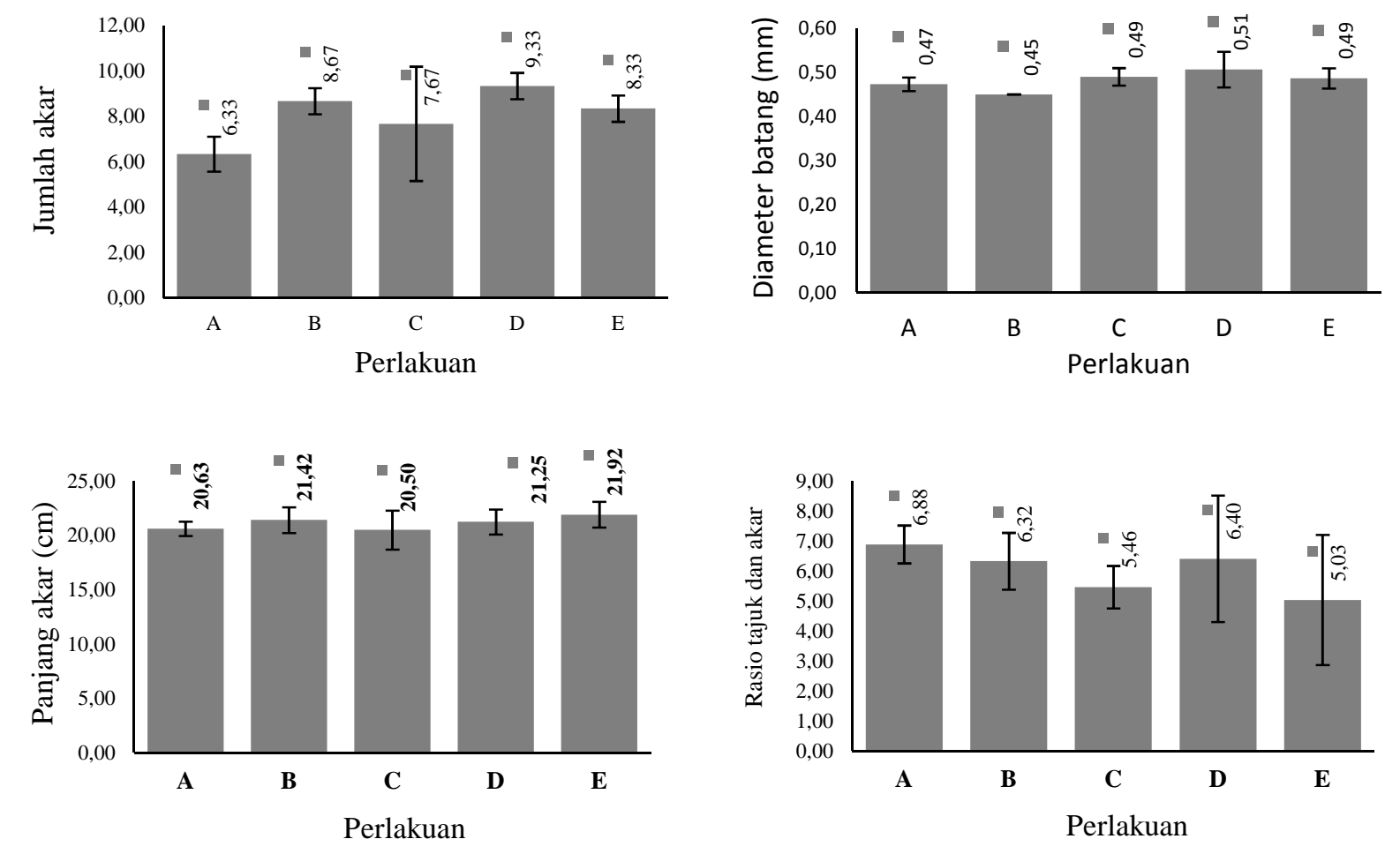

Gambar 1. Pengaruh aplikasi PHB terhadap bibit pala pada umur 4 BST.

Bakteri Bacillus subtilis dilaporkan dapat memproduksi IAA (auksin), sitokinin dan giberelin ${ }^{[7,12]}$ dan etilen ${ }^{[13]}$. Fitohormon dapat dihasilkan oleh mikroorganime baik pada kultur murni maupun pada asosiasi dengan tanaman ${ }^{[14]}$. Hal ini memungkinkan bakteri stain Bacillus sp yang digunakan sebagaierlakuan dapat memproduksi fitohormon pada kultur murni (carrier kultur cair) sehingga jika diaplikasikan dengan cara semprot pada tanaman akan cepat menimbulkan reaksi terhadap peningkatan pertumuhan tanaman.

Bacillus sp adalah bakteri tanah yang hidup ditanah terutama disekitar perakaran tanaman. Di dalam tanah, bakteri dapat mengkolonisasi permukaan akar, serta memproduksi fitohormon auksin, sitokinin, giberelin, dan etilen yang mempengaruhi plorifierasi sel pada sistem perakaran tanaman sehingga membentuk lebih banyak akar lateral dan rambut akar untuk meningkatkan penyerapan hara dan air. Hal ini terbukti terjadi pada penelitian ini, yakni terjadinya peningkatan tinggi tanaman, bobot kering tajuk, bobot kering akar, dan bobot kering tanaman (tajuk + akar) secara signifikan. Fungsi hormon IAA bagi tanaman antara lain meningkatkan perkembangan sel, merangsang pembentukan akar baru, memacu pertumbuhan, merangsang pembungaan dan meningkatkan aktivitas enzim. Selanjutnya dikemukakan juga bahwa IAA dan enzim nitrogenase terbukti meningkatkan bobot kering dan pengambilan hara tanaman ${ }^{[15]}$.

Selain fitohormon, bakteri Bacillus dikenal sebagai bakteri pelarut fosfat ${ }^{[5,16,17]}$. Dalam tanah, fosfat terdapat di dalam bentuk 
senyawa organik dan anorganik, namun 95-99\% fosfat yang ada secara alami dalam bentuk terikat, tidak terlarut dan mengendap

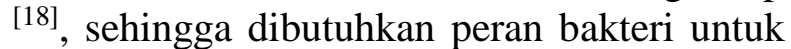
melalutkan forfat sehingga dapat dimanfaatkan oleh tanaman. Tanaman umumnya menyerap fosfat dalam bentuk ion $\mathrm{H}_{2} \mathrm{PO}_{4}$ dan HPO4 -2 ${ }^{[19]}$. Mekanisme kerja bakteri dalam meningkatkan ketersediaan fosfat melalui tiga cara yaitu: (1) mengeluarkan senyawa mineral kompleks seperti anion asam organik, proton, ion hidroksil, dan $\mathrm{CO}_{2}$; (2) membebaskan enzim ektraseluler (mineralisasi fosfat melalui reaksi biokimiawi); dan (3) membebaskan fosfat pada saat dekomposisi substrat (mineralisasi fosfat melalui proses biologis) ${ }^{[20,21]}$.

Bakteri Bacillus juga mampu meningkatkan ketersediaan unsur kalium dengan meningkatkan kelarutan batuan yang mengandung hara $\mathrm{K}$ melalui produksi dan sekresi asam organic [22], membantu penyediaan unsur $\mathrm{Fe}$ melalui mekanisme siderofor yang melibatkan asimilasi spesifik untuk menghasilkan senyawa Fe-kelat berbobot molekul rendah (siderofor) sehingga dapat dimanfaatkan tanaman ${ }^{[23]}$. Perananan siderofor dapat meningkatkan kandungan klorofil pada daun ${ }^{[20]}$.

Dengan mengetahui kemampuan bakteri Bacillus sp terhadap peningkatan pertumbuhan tanaman melalui kerja fitohormon, menyediakan unsur fosfat dan kalium, serta peningkatan klorofil melalui peranan siderofor, dimana fitohormon dapat dihasilkan pada kultur murni maupun ketika berasosiasi dengan tanaman, maka terbukti dalam penelitian ini, aplikasi PHB pada tanaman bibit melalui cara semprot pada tanaman maupun cocor pada tanah dibagian batang, keduanya memiliki pengaruh yang sama terhadap pertumbuhan bibit pala.

\section{KESIMPULAN}

1. Pemberian pupuk hayati konsorsium strain Bacillus sp (PHB) dengan konsentrasi $0,15 \%$ dan $0,30 \%$, dan diaplikasi dengan cara disemprot pada tanaman di bagian daun dan dikocor pada tanah sekitar pangkal batang tanaman berpengaruh terhadap tinggi tanaman, bobot tajuk, bobot akar dan bobot kering tanaman, tetapi tidak berpengaruh terhadap jumlah akar, panjang akar, diameter batang, dan rasio bobot kering tajuk dan akar pada bibit tanaman pala umur empat bulan setelah tanam di polibag. Pemberian $\mathrm{PBH}$ dengan konsentrasi $0,30 \%$ memberikan pengaruh lebih baik dibandingkan dengan konsentrasi $0,15 \%$. Sedangkan pengaruh dari cara pemberian dikocor dan disiram adalah sama.

2. Untuk meningkatkan pertumbuhan bibit pala dapat menyemprot atau menyiram tanaman dengan PHB konsentrasi 0,30\%.

3. Pemberian PHB merupakan solusi untuk meningkatkan pertumbuhan bibit pala secara natur dan berkelanjutan.

\section{DAFTAR PUSTAKA}

[1] Leatemia J.A., Kalay, A.M., Patty, J.A., Rumthe R.Y., Hasinu, J.V.G., Tuhumury, G.N.C., Noya, S.H., Rumahlewang, W, dan H. Rehataet. 2014. Pendataan Masalah Organisme Pengganggu Tanaman (OPT) pada Tanaman Cengkeh dan Pala di Provinsi Maluku. Laporan Kerjasama Dinas pertanian Provinsi Maluku dengan Fakultas Pertanian Unpatti. Ambon.

[2] BPS. 2019. Maluku dalam angka Tahun. Badan Pusat Statistik Provinsi Maluku, Ambon.

[3] Sinha, R.K., Valani, D., Chauhan, K, and S. Agarwal. 2014. Embarking on a second green revolution for sustainable agriculture by vermiculture biotechnology using earthworms: reviving the dreams of $\mathrm{Sir}$ Charles Darwin. Int J Agric Health Saf. 1:50-64. 
[4] Cattelan, A.J., Hartel, P.G, and J.J. Fuhrmann. 1999. Screening for plant growth-promoting rhizobacteria to promote early soybean growth. Soil Sci.Soc.Am.J. 63: 1.670-1.680.

[5] Syarifudin, A. 2002. Teknik identifikasi mikroorganisme penyedia unsur hara tanaman pada ultisols pulau Buru. Bulletin Teknik Pertanian 7(1) : 21-24.

[6] Mukamto., Ulfah, S., Mahalina, W., Syauqi, A., Istiqfaroh, L. dan G. Trimulyono. 2015. Isolasi dan Karakterisasi Bacillus sp. Pelarut Fosfat dari Rhizosfer Tanaman Leguminosae. Sains dan Matematika 3(2): 62-68.

[7] Kesaulya, H., Baharuddin, H., Zakaria, B. and S.A. Syaiful. 2015. Isolat and Physiological Chacterization of PGPR from Potato Plant Rhizosphere in Medium Land of Buru Islan. Procedia Food Science 3 : 190-199.

[8] Sukmadi R. B. 2012. Aktivitas Fitohormon Indole-3-Acetic Acid (Iaa) Dari Beberapa Isolat Bakteri Rizosfer dan Endofit. Jurnal Sains dan Teknologi Indonesia, 14 (3): 221-227.

[9] Asroh, A. 2010. Pengaruh Takaran Pupuk Kandang dan Interval Pemberian Pupuk Hayati terhadap Pertumbuhan dan Hasil Tanaman Jagung Manis (Zea mays Saccharata Linn). J. Agronomi. 2 (4): 144-148.

[10] Murray, R.K., Granner, D.K., Mayes, P.A. and V.W. Rodwell. 2005. Harper's Illustrated 13 Biochemistry. TwentySixth Edition. New 62 Suryadi, dkk. York: McGraw-Hill.

[11] Suryadi., Y., Priyatno, T.P., Susilowati, D.N., Samudra, I.M., Yudhistira, N. and E.D. Purwakusumah. 2013. Isolasi dan Karakterisasi Kitinase asal Bacillus cereus Jurnal Biologi Indonesia 9(1): 5162.

[12] Glick, B.R. 2014. Bacteria with ACC deaminase can promote plant growth and help to feed the world. Microbiological Research, 169(1), 30-39.

[13] Premachandra, D., Hudek, L. and L. Brau. 2016. Bacterial modes of action for enhancing of plant growth. Journal of Biotechnology \& Biomaterials, 6: 3.

[14] Hanafiah, K.A., Anas, I., Napoleon, A. and N. Ghoffar. 2005. Biologi tanah (ekologi dan makrobiologi tanah ). Grafindo Persada. Jakarta. 165 halaman.

[15] Egamberdiyeva, D. 2007. The effect of PGPR on Growth and Nutrient Uptake of Maize in Two Different Soils. Applied Soil Ecology. Vol.36(1): 184-189.

[16] Deshwal, V and K.P. Kumar. 2013.Production of Plant growth promoting substance by Pseudomonads. Journal of Academia and Industrial Research (JAIR). 2: 221-225.

[17] Habibi, S., Djedidi, S., Prongjunthuek, K., Mortuza, M.F., Ohkama-Ohtsu, N., Sekimoto, H. and T. Yokoyoma. 2014. Physiological and genetic characterization of rice nitrogen fixer PGPR isolated from rhizosphere soils of different crops. Plant and Soil. 379: 5166

[18] Alori, E. T., Glick, B.R. and O.O. Babalola. 2017. Microbial phosphorus solubilization and its potential for use in sustainable agriculture. Frontiers In Microbiology, 8, 971.

[19] Bhattacharyya, P. N., and D. K. Jha. 2012. Plant growth-promoting rhizobacteria (PGPR): emergence in agriculture. World Journal of Microbiology and Biotechnology, 28(4): 1327-1350.

[20] Sharma, S. B., Sayyed, R.Z., Trivedi, M.H. and T.A. Gobi. 2013. Phosphate solubilizing microbes: sustainable approach for managing phosphorus deficiency in agricultural soils. Springer Plus, 2: 587. Retrieved from http://www.springerplus.com/content/2/ $1 / 587$

[21] Oteino, N., Lally, R.D., Kiwanuka, S., Lloyd, A., Ryan, D., Germaine, K.J. and D.N. Dowling. 2015. Plant growth 
promotion induced by phosphate solubilizing endophytic Pseudomonas isolates. Frontiers in Microbiology, 6, 745.

[22] Parmar, K.B., Mehta, B.P. and M.D. Kunt. 2016. Isolation, characterization and identification of potassium solubilizing bacteria from rhizosphere soil of maize (Zea mays), 5(5): 30303037.
[23] Radzki, W., Gutierrez Mañero, F.J., Algar, E., JLucas García A., GarcíaVillaraco, A., and S.B. Ramos. 2013. Bacterial siderophores efficiently provide iron to iron-starved tomato plants in hydroponics culture. Antonie van Leeuwenhoek, International Journal of General and Molecular Microbiology, 104(3): 321-330. 